\title{
Youth entrepreneurial projects for the sustainable development of global community: evidence from Enactus program
}

\author{
Anastasiia Dalibozhko ${ }^{1, *}$, and Inna Krakovetskaya ${ }^{1}$ \\ ${ }^{1}$ National Research Tomsk State University, Institute of Economics and Management, 2 Novo- \\ Sobornaya 1 Square, 634050 Tomsk, Russian Federation
}

\begin{abstract}
Achievement of sustainable development that meets the needs of the present day without compromising the ability of future generations to meet their own needs, increasingly becoming a global agenda in addressing economic, environmental and social problems. This study raises the question of the possibility to achieve United Nations Sustainable Development Goals on the basis of involving young people into entrepreneurial projects. The object of the study is an international Enactus program, which originated in the US and now brings together students and business leaders in 36 countries (including Poland and Russia). The research methodology is based on the Triple Bottom Line Conception (a way of accounting factors in economic, environmental, and social impacts) and includes analysis of literature, comparison, generalization, content analysis, and the processing of empirical data obtained during interviewing Enactus students. The main findings of the study include the analysis of Enactus projects in terms of their relevance to the concept of sustainable development and the UN goals. The contribution of projects to the sustainable development of the world community has been assessed. On the basis of successful Tomsk State University experience substantiates the need to form joint international economic, ecological and social projects to solve current global problems more effectively.
\end{abstract}

\section{Introduction}

At the present stage of development there is a steady growth of the world community's concern regarding the further ways of development of mankind. Indeed, the changes caused by the development of science and technology, globalization and the creation of a united global information space, environmental degradation and the deepening of social contradictions are a characteristic feature of a modern postindustrial society [1].

The world economic crisis further exacerbated the economic, social and environmental problems of modern society. The main concern consists of those problems such as pollution and toxic waste, deforestation and extinction, energy demand, food and water security, climate change. Similarly, changes in other aspects such as social, economic, political, defense and culture, will also change the world order [2]. All these new challenges for the

\footnotetext{
*Corresponding author: anastasia.dalibozhko@gmail.com
} 
world community are related to the core question: how will a growing population live on a polluted, finite, and changing planet?

In this study was made an attempt to justify the possibility of solving global environmental, economic and social problems by involving the youth in entrepreneurial projects (as an example was Enactus international program). The analysis of the correspondence of the implemented projects to the United Nations sustainable development goals was carried out, the contribution to the solution of current global problems is shown.

\section{Methodology}

The research methodology includes analysis of literature, comparison, generalization, content analysis, and the processing of empirical data obtained during interviewing Enactus international program students.

\section{Theoretical basis of the research}

The theoretical model of the study is based on the Triple Bottom Line concept of sustainable development. The UN goals of sustainable development are analyzed. Enactus student projects are considered in terms of their relevance to the sustainable development concept and the UN goals.

\subsection{Sustainable development concept: from the "wicked" problem to the solutions}

Numerous discussions and studies on the field of modern challenges led to the emergence of a new global concept of human development, which became known as the sustainable development concept. In the UN report "World Commission on Environment and Development: Our Common Future" (1987) the following definition of sustainable development was given: this development "meets the needs of the present without compromising the ability of future generations to meet their own needs" [3]. At the same time sustainable development "is not a fixed state of harmony, but rather a process of change in which the exploitation of resources, the direction of investments, the orientation of technological development, and institutional change are made consistent with future as well as present needs" [3].

This concept is based on the idea of a "wicked" problem. It is a problem that is not easy solved because it has many interconnected causes, many stakeholders, and continually changing. In addition, due to complex interdependencies, efforts to address one aspect of the "wicked" problem can reveal or create other problems. This problem combines environmental, biological, social, cultural, economic and political causes, continually changes, solving it often means changing behavior, trade-offs, and it can never be completely solved.

Usually, part of the solution to wicked problems involves changing the behaviour of groups of citizens or all citizens. Other key ingredients in solving or at least managing complex policy problems include successfully working across both internal and external organisational boundaries and engaging citizens and stakeholders in policy making and implementation. Wicked problems require innovative, comprehensive solutions that can be modified in the light of experience and on-the-ground feedback [4].

In fact, the "wicked" problems relate to the economic, environmental and social challenges facing modern society, and their solution can be based on the implementation of the sustainable development concept. 
At the same time, achieving sustainable development is impossible without long-term thinking and reliance on the Triple Bottom Line concept.

\subsection{Triple Bottom Line concept: the basis of sustainability}

The phrase "the triple bottom line" as a concept was first coined in 1994 by John Elkington, the founder of a British consultancy called SustainAbility [5], and then was further developed in the book "Cannibals with Forks: the Triple Bottom Line of 21st Century Business" [6]. This concept includes a way of business accounting that factors in economic, environmental and social impact.

John Elkington identifies the "Triple Bottom Line" or "Triple-P (People, Planet, Profit)" concept: Sustainability is about the balance or harmony between economic sustainability, social sustainability and environmental sustainability [7].

Graphically this relationship can be represented as the intersection of three circles (see Fig. 1.) [8]. And only when all three factors are taken into account (the intersection of all elements is the center), we can speak of achieving stability.

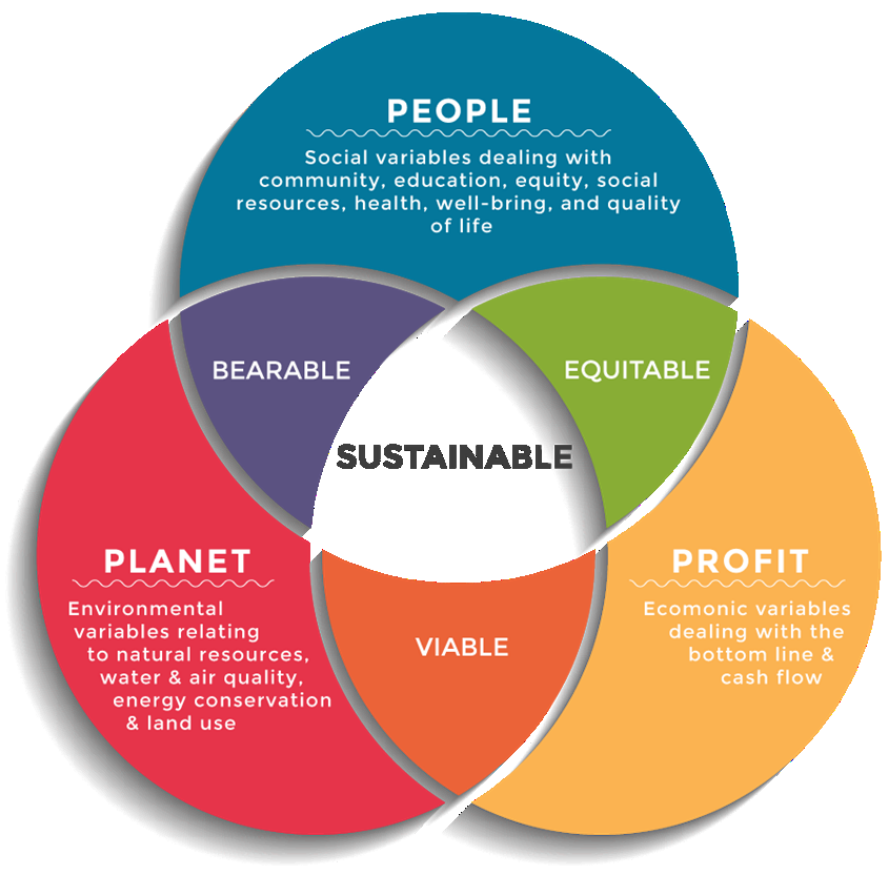

Fig. 1. The interconnection of the elements of the Triple Bottom Line concept.

"People" (or social dimension) focuses on the impacts organizations have on the communities in which they operate, also known as corporate responsibility. "Planet" (or environmental dimension) focuses on direct impact on ecosystems, land, air, and water based on operational inputs and outputs. "Profit" (or economic dimension) focuses on financial impact on total Enterprise level, usually expressed in monetary terms such as the efficient use of resources, sales/ profit (ROI), cost savings, job creation and product advantages.

This approach represents a conceptual tool for assessing sustainability and allows to answer the question: what are a business's economic, environmental, and social impacts? In 
this case, the positive impact can be seen as the sustainable condition, and negative impact as the unsustainable condition.

The practical applicability of this concept is justified by F. Slaper and T. J. Hall [9]. Thus, it is noted that businesses, nonprofits and government entities alike can all use the Triple Bottom Line. Also Triple Bottom Line concept can be used regionally by communities to encourage economic development growth in a sustainable manner. This requires an increased level of cooperation among businesses, nonprofit organizations, governments and citizens of the region.

In this regard, sustainable development can be characterized as socially desirable, economically viable and environmentally sustainable development of society. This model implies a close interconnection of environmental, social and economic goals, to which (as a whole) sustainable development is aimed. At the same time, this approach is applicable both to mankind as a whole and to communities of a lower level - to individual nationalities, cities, organizations, etc. [1]. Thus, we can say that the goals of sustainable development coincide with the goals of civilization in general.

\subsection{UN sustainable development goals: new challenges to the new reality}

The sustainable development goals for 2016-2030, set at the UN Summit, imply the coherence of economic growth, human development, environmental protection. 17 Sustainable Development Goals (see Fig.2) [10] and 169 objectives were unanimously adopted by 193 States Members of the United Nations at the historic Summit, held in New York in September 2015.

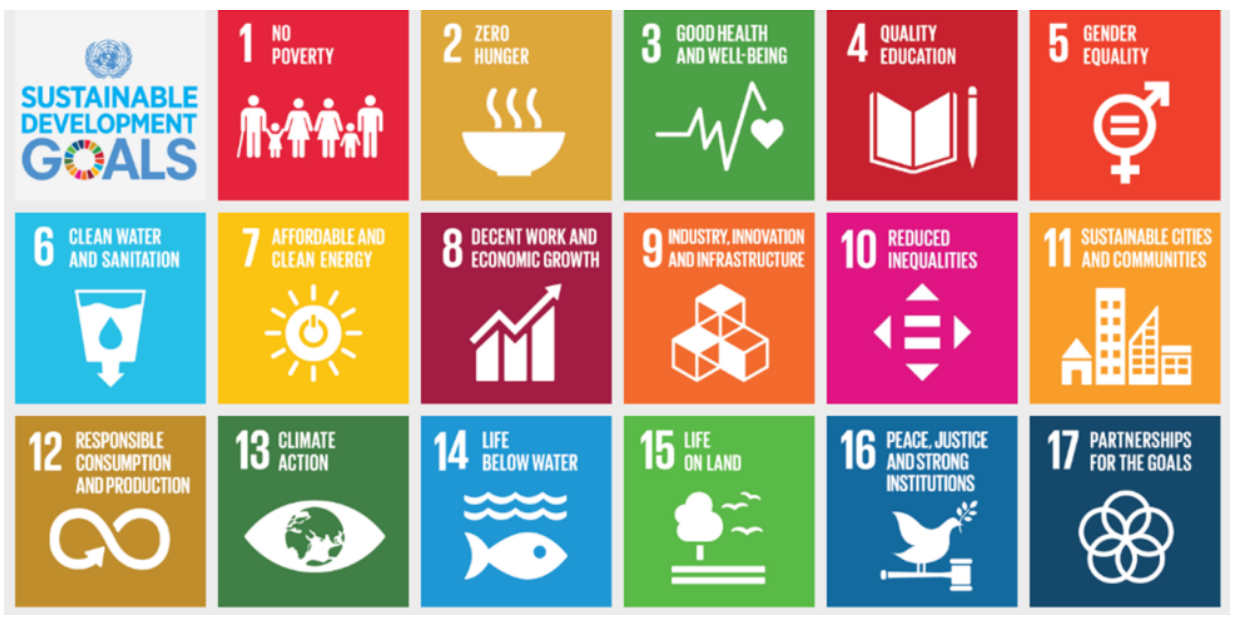

Fig. 2. UN sustainable development goals.

New goals and objectives for 2016 - 2030 cover a wider range of issues of social, economic and environmental development in their relationship, in comparison with the Millennium Development Goals [11]. A significant part of the goals of sustainable development, being social, or environmental, or economic, is designed to contribute to the achievement of other goals simultaneously. The sustainable development goals, in contrast to the Millennium Development Goals [6], are more global. Their achievement requires joint efforts of governments, international organizations and world leaders.

Although significant achievements have recorded with respect to the MDG targets worldwide, progress has been uneven across regions and countries, leaving significant gaps. Millions of people are being left behind, especially the poorest and those disadvantaged 
because of their sex, age, disability, ethnicity, or geographic location [6]. As noted by Z. Wysokinska, "this new, wider approach better reflects the global changes and is based on the conviction that the elimination of poverty and sustainable development are strictly interconnected and mutually reinforcing" [12]. For these reasons sustainable development goals are focused on three dimensions: social, economic, and ecological.

\subsection{Enactus international program: projects for the sustainable development}

One of the opportunities that fosters the inclusion of the youth in entrepreneurial projects can be participation in the international Enactus program [13] - the largest non-profit organization that unites students, business leaders, universities. Enactus teams develop and implement projects aimed at improving the quality and standard of living of people. Enactus is the world's largest experiential learning platform dedicated to creating a better world while developing the next generation of entrepreneurial leaders and social innovators. The Enactus network of global business, academic and student leaders are unified by our vision - to create a better, more sustainable world.

Originating in the US in 1975, the Enactus program has been successfully developed to include 36 countries around the world. The number of teams in the context of different countries is shown in Fig. 3. (compiled by the authors on the basis of the analysis of the Enactus Worldwide official webpage).

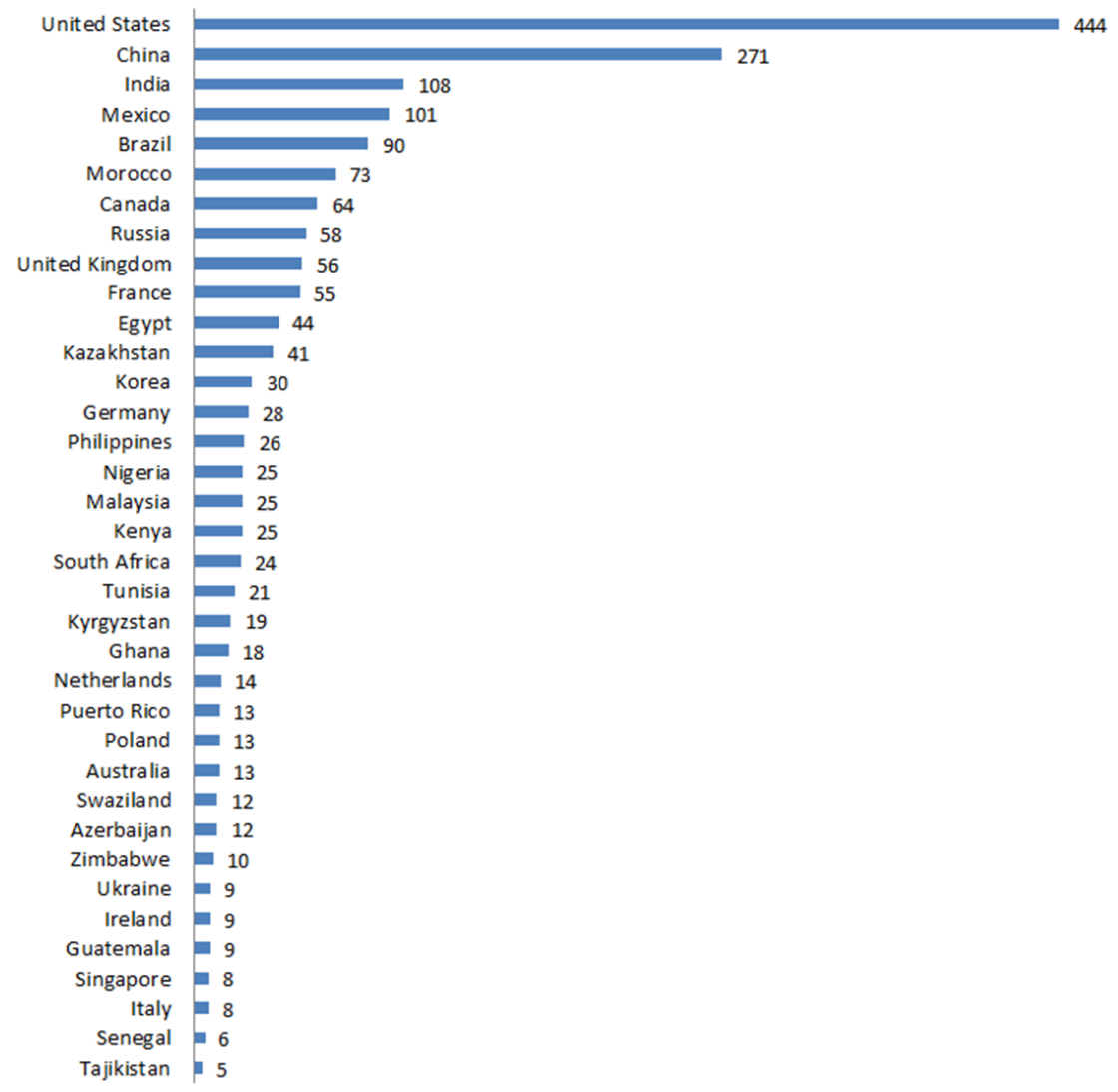

Fig. 3. Number of Enactus teams (as for 2018). 
72,000 Enactus students are entrepreneurial, values-driven social innovators across 1,730 campuses in 36 countries, positively impacting the lives of 1.3 million people each year. Guided by educators and supported by business leaders, teams of students conduct needs assessments in their community, identify potential solutions to complex issues and implement community impact projects. This results in communities benefiting from collaboration and fresh innovation, plus students gain the valuable experience to advance their personal and professional lives.

Together, the teams implement a staggering 3725 projects (see Fig. 4) (compiled by the authors on the basis of the analysis of the Enactus Worldwide official webpage), contributing both to the development of the local and global community. The topics of Enactus projects includes all 17 sustainable development goals adopted by the United Nations in "Transforming our world: the 2030 Agenda for Sustainable Development". In addition, each of the Enactus projects takes into account all three groups of factors in the Triple Bottom Line concept and aims at creating a more sustainable world.

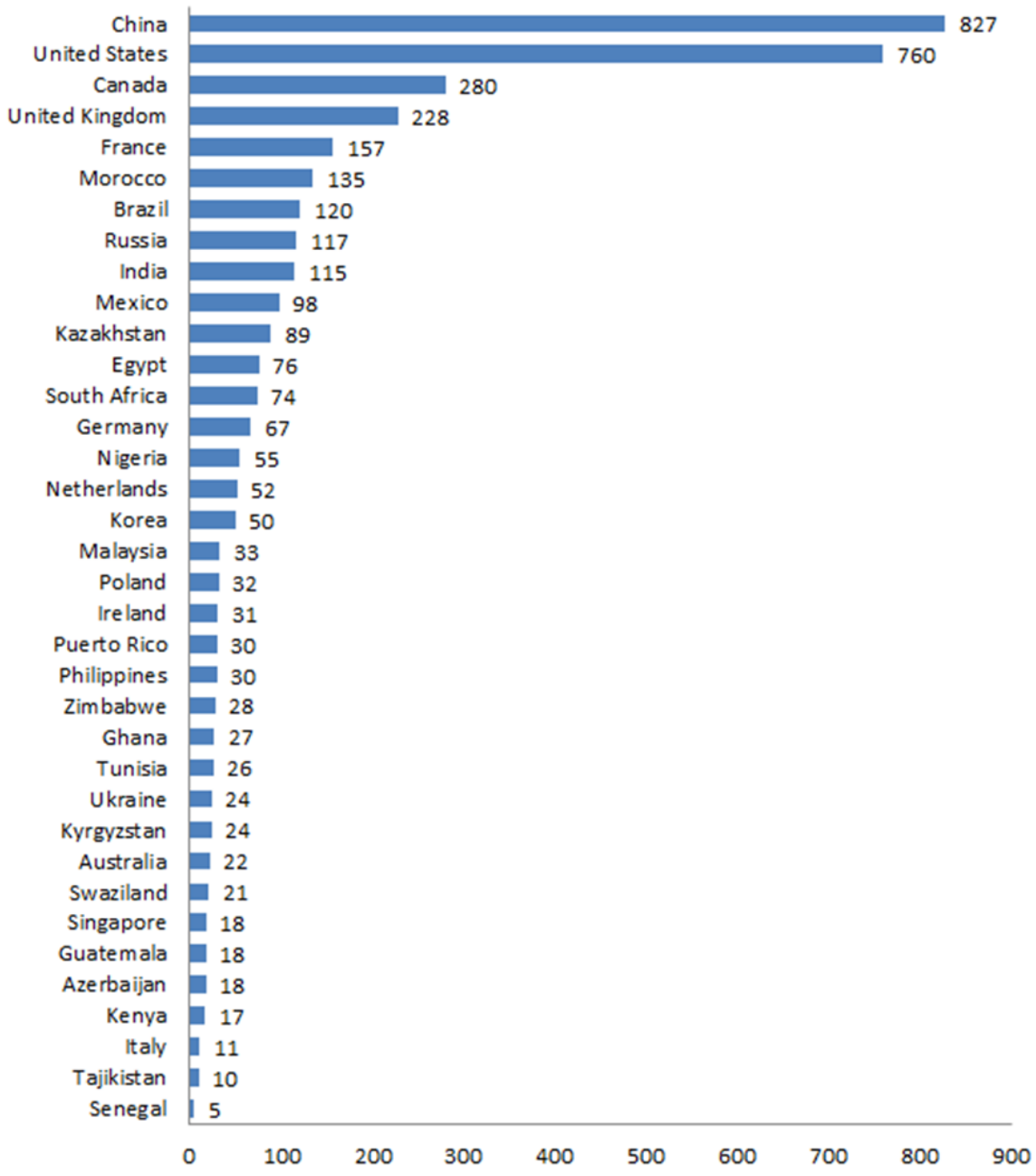

Fig. 4. The number of Enactus projects implemented by teams (as for 2018). 


\section{Results}

Based on the study of the official Enactus website, as well as the content analysis of the annual reports of the Enactus teams, we have classified the projects according to the purposes of the UN. The ratio of 5 most popular team projects is given below depending on which of the global goals is in focus (see Fig. 5.).

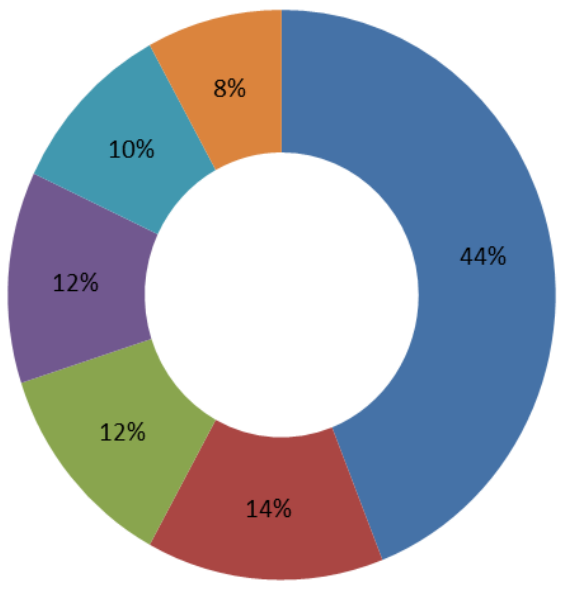

n Others

- Zero hunger

- Clean water and sanitation

Decent work and economic growth

affordable and clean energy

No poverty

Fig. 5. Classification of Enactus teams projects in compliance with sustainable development goals adopted by the United Nations (as for 2016).

The teams conduct an in-depth assessment of the needs together with the target audience, and looking for ways of real and measurable improvement in the life of the target audience that creates the basis for sustainable development. When developing projects, Enactus teams collaborate with business, administration, innovators, retired people, students and villagers, helping to improve their quality of life.

The authors of this article present the results obtained on the basis of the experience of forming joint international projects within the framework of the Enactus program. Tomsk State University hosted the International Winter School "Social Entrepreneurship", in which took part students from the International Enactus Program from 8 countries: Russia, India, Morocco, France, Canada, Great Britain, Brazil, Kazakhstan and Kyrgyzstan [14]. The Winter International School envisioned a ten-day series of master classes, round tables, presentations of participating teams' projects, and, of course, the exchange of experience in project activities in the area of social entrepreneurship.

As part of the school's work, students of Enactus teams were asked to create projects aimed at solving $17 \mathrm{UN}$ sustainable development goals. The school participants chose 5 goals: zero hunger, access to clean water and sanitation, good health and well-being, quality education, decent work and economic growth, and developed the concept of an international project for each of them (see Table 1.).

Table 1. Possible joint international socio-economic projects.

\begin{tabular}{|c|l|l|}
\hline $\begin{array}{c}\text { UN sustainable } \\
\text { development goal }\end{array}$ & Project name & \multicolumn{1}{|c|}{ Brief description of the project } \\
\hline Quality education & Engilabs & $\begin{array}{l}\text { Creating children's engineering hubs and } \\
\text { developing schools in villages and remote }\end{array}$ \\
\hline
\end{tabular}




\begin{tabular}{|l|l|l|}
\hline $\begin{array}{c}\text { UN sustainable } \\
\text { development goal }\end{array}$ & \multicolumn{1}{|c|}{ Project name } & \multicolumn{1}{|c|}{ Brief description of the project } \\
\hline $\begin{array}{l}\text { Good health and } \\
\text { well-being }\end{array}$ & $\begin{array}{l}\text { AME - Available } \\
\text { Medical } \\
\text { Education }\end{array}$ & $\begin{array}{l}\text { areas } \\
\text { The program of training medical care and } \\
\text { principles of healthy lifestyles for the } \\
\text { inhabitants of small villages }\end{array}$ \\
\hline Zero hunger & Zero Hunger & $\begin{array}{l}\text { A platform for cooperation of entrepreneurs, } \\
\text { experts in the field of biology, agronomy, } \\
\text { soil science, etc., as well as financial } \\
\text { sponsors that will help residents of different } \\
\text { regions to provide themselves with food }\end{array}$ \\
\hline $\begin{array}{l}\text { Decent work and } \\
\text { economic growth }\end{array}$ & $\begin{array}{l}\text { Discover Tomsk, } \\
\text { the heart of } \\
\text { Siberia }\end{array}$ & $\begin{array}{l}\text { The program of additional earnings of the } \\
\text { inhabitants of Siberian cities and villages in } \\
\text { the sphere of internal and external tourism }\end{array}$ \\
\hline $\begin{array}{l}\text { Access to clean } \\
\text { water and sanitation }\end{array}$ & $\begin{array}{l}\text { Paani Project } \\
\text { Creation and implementation of an } \\
\text { innovative, efficient device for desalination } \\
\text { of water }\end{array}$ \\
\hline
\end{tabular}

Winter School has become a platform for meetings like-minded Enactus team members: students worked in international teams on projects that are relevant to the entire world community. The main goal of such events is to give a start, after which students from different countries can continue working on international projects in a format that is convenient for them.

\section{Main conclusion}

In general, it can be noted that the problems of sustainable development of the world community have been actualized in recent years. The theories that appeared earlier get a new development, with an increasing emphasis on a comprehensive consideration of the factors of society, economics, ecology in their close interconnection and interdependence. Sustainable development is becoming a global agenda and the main issue not only in regions, but in the world as a whole.

In such conditions it is extremely important to include the local community in solving global problems. The youth, as a more active part of the population, can be included in entrepreneurial projects aimed at creating a more sustainable world and solving global goals of the UN agenda.

The materials of the research show that Enactus projects, especially when teams from different countries join forces, can become a basis for sustainable development and a way of including the population (both directly and indirectly - as a target audience) in solving actual problems of our time.

The paper has been prepared within the financial support of Russian Foundation for Basic Research grant "Business-model of Companies as the Basis for Forming Shared Values and Social Capital" \# 18-010-00340.

\section{References}

1. A.I. Grishin, M.S. Mel'nikov, I.A. Stroganov, Academy's Herald, 1, 9-15 (2015)

2. Y.J. Utama, A. Ambariyanto, M. Zainuri, D. Darsono, B. Setyono, Widowati, S.P. Putro, Journal of Physics: Conference Series Volume 1025, 1 (2018) 
3. World Commission on Environment and Development. Our Common Future. Retrieved from: http://www.un-documents.net/our-common-future.pdf (1987)

4. Australian Public Service Commission. Tackling Wicked Problems: A Public Policy Perspective, http://www.enablingchange.com.au/wickedproblems.pdf (2007)

5. J. Elkington, California Management Review 36, 2, 90-100 (1994)

6. Millennium Development Goals Report 2015. United Nations, New York (2015)

7. J. Elkington. Cannibals with Forks: the Triple Bottom Line of 21st Century Business (Capstone Publishing Ltc., Oxford, 1997)

8. What is sustainability? Salisbury University. Retrieved from: http://www.salisbury.edu/sustain/about/whatissustainability.html (2018)

9. T.F. Slaper, T. J. Hall, Indiana Business Review, 86(1) (2018)

10. United Nations Sustainable Development Knowledge Platform. Sustainable Development Goals. Retrieved from: https://sustainabledevelopment.un.org/?menu=1300 (2015).

11. N.E. Petrovskaya, Russia and America in the 21st century, 3, 21 (2016)

12. Z. Wysokinska., Comparative Economic Research, 20(1), 101-118 (2017)

13. Official website of Enactus Worldwide. Retrieved from: http://www.enactus.org (2018)

14. I. Krakovetskaya, A. Dalibozhko, I. Slesarenko. Proceedings of the 31st International Business Information Management Association Conference (IBIMA), Milan, Italy, 2454-2466 (2018). 